\title{
Biodegradation of Phenol by Curtobacterium flaccumfaciens: Optimization of Growth Conditions
}

\author{
Ibrahem S. Almajali ${ }^{1 *}$, Amjad Al-Tarawneh ${ }^{3}$, Haitham Qaralleh ${ }^{1}$, \\ Muhamad Al-Limoun², Mutaz M. Al-Sarayrah², Moath Alqaraleh ${ }^{4}$, \\ Walid Abu Rayyan ${ }^{5}$, Khaled M. Khleifat ${ }^{2}$, Saif M Dmour ${ }^{6}$ \\ ${ }^{1}$ Department of Medical Laboratory Sciences, Mutah University, Mu’tah, Karak 61710, Jordan \\ ${ }^{2}$ Mutah University, Department of Biology, Karak, Mutah 61710, Jordan \\ ${ }^{3}$ Prince Faisal Center for Dead Sea, Environmental and Energy Research, Mu'tah University, Jordan \\ ${ }^{4}$ Pharmacological and Diagnostic Research Center (PDRC), Faculty of Pharmacy, \\ Al-Ahliyya Amman University, Amman 19328, Jordan \\ ${ }^{5}$ Department of Pharmacology and Medical Sciences, Faculty of Pharmacy, University of Petra, Amman, Jordan \\ ${ }^{6}$ Department of Medical Analysis, Prince Aisha Bint AL-Hussein, Faculty of Nursing and Health Science \\ ALHussein Bin Talal University, Jordan
}

Received: 8 January 2021

Accepted: 22 April 2021

\begin{abstract}
Phenol is one of the most important environmental pollutants that are found in sewage and industrial water from which agricultural lands are irrigated. In this study Curtobacterium flaccumfaciens bacterium was isolated in pure culture from phenol-uncontaminated farmland soil. Its ability to biodegrade phenol was examined. C. flaccumfaciens demonstrated its ability to use phenol as a source of carbon and energy in batch cultures. The isolated strain was able to completely biodegrade $700 \mathrm{mg} / \mathrm{L}$ phenol in a reasonable incubation period $(96 \mathrm{~h})$. However, these bacteria were able to completely remove $700 \mathrm{mg} / \mathrm{L}$ of phenol in a reasonable incubation period $(96 \mathrm{~h})$. The degradation rate of phenol was $19.4 \mathrm{ppm} / \mathrm{h}$. However, they also endured higher concentrations than $1200 \mathrm{mg} / \mathrm{L}$, but had a lower biodegradation rate because of cytotoxicity generated by phenol concentration of more than $700 \mathrm{mg} / \mathrm{L}$. It was observed that the biodegradation process of phenol occurred at $\mathrm{pH} 7.0$ to obtain maximum degradation of phenol by $C$. flaccumfaciens. In addition, the biodegradation of phenols occurred over a large range of incubation temperature $\left(25\right.$ to $\left.37^{\circ} \mathrm{C}\right)$ where $28^{\circ} \mathrm{C}$ was the optimum incubation temperature for C. flaccumfaciens cells for phenol biodegradation. Since this is, the first study related to the use of $\mathrm{C}$. flaccumfaciens in the biodegradation process of phenol, more works need to be done, whether from a biochemical or molecular biology point of view.
\end{abstract}

Keywords: biodegradation, Curtobacterium flaccumfaciens, phenol, growth conditions

*e-mail: majali201181@yahoo.com 


\section{Introduction}

Phenol is considered as one of the major pollutant material that have a hazardous impact on environment and that can be very risky to human health. They persist in their surroundings they are found in contaminate stream, river, and ground water. Once these aromatic ring enter into the food cycle, their high longevity allows biological accumulation within animal tissue (including human) they can cause several organ problems to human such as liver damage, hemolytic anemia and paralysis. The major source of phenol arises from human industrial activities such as petroleum processing, plastic manufacturing, and the production of resins $[1,2]$.

Phenol is one of the organic aromatic pollutants that is listed in the record of United Nations Environmental Protection Agency (EPA). It might cause death by oral intake, direct inhalation and skin imbibition due to its quickly penetration and absorption by the skin and phenol considered as a carcinogenic compounds [3-5].

Many techniques- chemical or physical have been used for the elimination of phenol including ion exchange, activated carbon adsorption, chemical oxidation and liquid-liquid extraction, but these techniques have led to of serious defects such as their need for large and are costly. Besides that, the majority of these processes do not degrade phenol, but rather convert it to another stage, which leads to the formation of dangerous by-products (secondary pollutants). In contrast, elimination of phenol by living cells (biodegradation) is an environmentally friendly and more cost-effective alternative. Thus, the biodegradation of phenol can be an increasingly important process in combating pollution [6-12].

Many researchers focused on the ability of microorganisms to uses phenol as a source of carbon and energy, Aspergillus awamori cells were degraded high concentration of phenol, catechol, 2,4-dichlorophenol, and 2,6-dimethoxyphenol [13, 14]. The effect of carbon starvation under optimum growth conditions showed high ability on phenol degradation by Ewingella americana [3]. Klebsiella oxytoca showed the capacity to utilize phenol at high phenol concentration where $75 \%$ of initial concentration of (100 ppm) which was completely degraded within $72 \mathrm{~h}$. The rate was increased with the initial Klebsiella oxytoca cell densities increasing and increasing aeration rate and the time required for complete degradation [1].

Adjei and Ohta, (2000) reported that phenol was fully utilized by the Burkholderia cepacia strain. It was reported that $P$. putida MTCC 1194 using 1000 and 500 $\mathrm{mg} / \mathrm{l}$ as initial concentrations of phenol and catechol. Although highly acclimatized to phenol, the bacteria showed an extended lag phase because of the high phenol concentration. Most of the studies pertaining to bacterial metabolism of phenol was aerobically performed, oxygen is used by the phenol hydroxylase enzyme for adding a second hydroxyl group $[1,15,16]$. During biodegradation of aromatic compounds as growth substrates they transformed to dihydroxy derivatives of either ortho or para before ring cleavage. The process of ortho hydroxylation of phenols causes production of analogical catechols. Thus, the extensive substrate specificity of phenol hydroxylase enzyme is not exceptional property. The mentioned enzyme needs two atoms of oxygen per each phenol to be hydroxylated, In general, aromatic ring cleavage could not occur without the presence of oxygen molecules [15, 17]. Little information is available on bacteria and their resistance to high concentrations of phenol as well as the high metabolic activity available by these bacteria. Therefore, there is still a need to isolate this kind of phenol-degrading bacteria that can grow and thrive in high concentrations of phenol.

Curtobacterium flaccumfaciens is a Gram-positive bacteria that can cause a variety of plants diseases, with characteristic small irregular rods shape cell, processing lateral flagella and the ability to persist in aerobic environments, and the cells having catalase enzyme $[18,19]$. The aim of this study is to evaluate the ability of gram positive Curtobacterium flaccumfaciens in phenol biodegradation under optimum conditions.

\section{Material and Methods}

\section{Bacterial Strain}

The bacterium used in the current study was $C$. flaccumfaciens bacterial strain, which was isolated from the Al-Ghweir station wastewater treatment plant in AlKarak Country, Jordan. It was identified by means of 16S rRNA techniques, Italy. The nucleotide accession number in Genbank was (MN083298). Its biochemical identity was reverified using the REMEL kit (RapID ONE and RapID NF plus systems) procedure; also the morphological characteristics were always being microscopically checked [19].

\section{Preparation of Calibration Curve for Phenol Using 4-Aminoantipyrine Method}

It was prepared to determine the phenol concentration from the absorbance of the unknown sample. In order to cover a wide range of phenol concentration from 100 to $1200 \mathrm{ppm}$ (following the below procedure). The concentrations of phenol solution $(100,300,500,700,900.1100$ and 1200) ppm were prepared by using HPLC grade phenol standard. The 4-aminoantipyrine method was performed on all of the above phenol concentrations. The phenol standard curve was done with respect to the absorbance values (phenol concentration vs. absorbance). Later, the standard curves was used to calculate the concentration of phenol from the absorbance of unknown sample. 


\section{Medium and Culture Conditions}

\section{Preparation of Mineral Medium with Phenol}

In order, to prepare this media; three solutions were prepared separately: (a), Phenol solution

It was prepared by dissolving $5 \mathrm{~g}$ in $200 \mathrm{ml}$ deionized water (the final concentration was 25,000 ppm). To avoid any possible temperature effect on phenol, this solution was filter sterilized. (b), Mineral media. It was prepared by dissolving the following ingredients in $1000 \mathrm{ml}$ Erlenmeyer flask: $1 \mathrm{~g}$ $\mathrm{K}_{2} \mathrm{HPO}_{4}, 1 \mathrm{~g} \mathrm{NH}_{4} \mathrm{NO}_{3}, 0.5 \mathrm{~g}\left(\mathrm{NH}_{4}\right)_{2} \mathrm{SO}_{4}, 0.5 \mathrm{~g} \mathrm{MgSO}_{4}$, $0.5 \mathrm{~g} \mathrm{KH}_{2} \mathrm{PO}_{4}, 0.5 \mathrm{~g} \mathrm{NaCl}, 0.02 \mathrm{~g} \mathrm{CaCl}_{2}, 0.02 \mathrm{~g}$ $\mathrm{FeSO}_{4}$. The media was then distributed in $125-\mathrm{ml}$ Erlenmeyer flasks containing the proper volume of mineral medium according to the phenol concentration needed and then autoclaving was made. (c), Wolfe's mineral solution. It was prepared by dissolving $1.5 \mathrm{~g}$ of nitrilotriacetic acid in $500 \mathrm{~mL}$ deionised water in $1000 \mathrm{ml}$ Erlenmeyer flask, the $\mathrm{pH}$ was adjusted by $\mathrm{KOH}$ to 6.5 to achieve the best solubility. Then the followings were added: $3 \mathrm{~g} \mathrm{MgSO}_{4} .7 \mathrm{H}_{2} \mathrm{O}, 1 \mathrm{~g} \mathrm{NaCl}$, $0.5 \mathrm{~g} \mathrm{MnSO}_{4} \cdot \mathrm{H}_{2} \mathrm{O}, 1 \mathrm{~g} \mathrm{FeSO} \mathrm{SH}_{4} .7 \mathrm{H}_{2} \mathrm{O}, 0.1 \mathrm{~g} \mathrm{CoCl}_{2} \cdot 6 \mathrm{H}_{2} \mathrm{O}$, $0.1 \mathrm{~g} \mathrm{CaCl}_{2}, 0.1 \mathrm{~g} \mathrm{ZnSO}_{4} .7 \mathrm{H}_{2} \mathrm{O}, 0.01 \mathrm{~g} \mathrm{CuSO}_{4} .5 \mathrm{H}_{2} \mathrm{O}$, $0.01 \mathrm{~g} \quad \mathrm{AlK}\left(\mathrm{SO}_{4}\right)_{2} .12 \mathrm{H}_{2} \mathrm{O}, \quad 0.01 \mathrm{~g} \quad \mathrm{H}_{3} \mathrm{BO}_{3}, \quad 0.01 \mathrm{~g}$ $\mathrm{Na}_{2} \mathrm{MoO}_{4} \cdot 2 \mathrm{H}_{2} \mathrm{O}$. The volume was then completed to the mark with distilled water and shake vigorously followed by sterilization using filter. Finally, the mineral media with phenol was prepared by adding $0.5 \mathrm{ml}$ Wolfe's and proper phenol volume to each flask based on the wanted phenol concentration. For example to achieve mineral media with 200-ppm phenol concentration, $0.5 \mathrm{ml}$ wolfe's solution and $0.4 \mathrm{ml}$ phenol solution were added to the $49.1 \mathrm{ml}$ mineral media. Moreover, for the $700 \mathrm{ppm}$; $0.5 \mathrm{ml}$ Wolfe's solution and $1.4 \mathrm{ml}$ phenol solution were added to the $48.1 \mathrm{ml}$ mineral media.

\section{Phenol Tolerance Experiment}

Phenolic toxicity on Curtobacterium flaccumfaciens was done in the current study by growing the bacteria on TSB with different concentrations of Phenol (200, $400,700,800,1000$, and 1200) for 96 hours at $28^{\circ} \mathrm{C}$ and $150 \mathrm{rpm}$. C. flaccumfaciens were cultured in the same media without phenol as well as media with phenol but without bacterial inoculums was used as positive and negative controls, respectively. To find out the phenolresistant bacteria and the optimum phenol concentration for bacterial growth as well as the bacterial surviving time, the absorbance of the cultured media was measured at $600 \mathrm{~nm}$.

\section{Growth Assessment and Phenol Degradation}

Curtobacterium flaccumfaciens ability to grow on phenol (as a sole of carbon source) was studied by growing Curtobacterium flaccumfaciens in TSB to the middle of exponential phase (OD at $600 \mathrm{~nm} \approx 0.50$ ). The bacterial cells were harvested at $4000 \mathrm{rpm}$ for 15 min by centrifuge. The OD was adjusted to 0.2 at $600 \mathrm{~nm}$ to be used later as an inoculum by washing and suspend the cells with mineral media. Mineral media with 700-ppm phenol concentration was prepared and inoculated with C. Alaccumfaciens. The bacterial growth behavior was monitored spectrophotometry at $600 \mathrm{nmfor} 12,24,36,48,60,72,84$, and $96 \mathrm{hrs}$. Same procedure was carried out for the control (mineral media with $700 \mathrm{ppm}$ phenol and without bacterial inoculation).

The elimination of phenol by bacteria was measured by collecting $1 \mathrm{ml}$ from each cultural flask at $12,24,36,48,60,72,84$, and $96 \mathrm{~h}$ for residual phenol concentrations measurements. The phenol concentration was then measured spectrophotometry at $510 \mathrm{~nm}$ following the 4-aminoantipyrine method [20]. The phenol concentration was finally obtained from the standard curve by installing the OD value on the standard curve equation. The degraded phenol value was calculated by subtracting the residual phenol from the initial phenol concentration.

\section{Phenol Degradation Assay}

$1 \mathrm{ml}$ of C. Alaccumfaciens broth with $0.2 \mathrm{OD}$ at $600 \mathrm{~nm}$ was inoculated into $125 \mathrm{ml}$ Erlenmeyer flasks containing $50 \mathrm{ml}$ mineral medium with phenol. The phenol concentration was determined by measuring the absorbance at $510 \mathrm{~nm}$ following the method of 4-Aminoantipyrine, which indicating the phenol degradation by decrease in absorbance with increasing time [21]. The average degradation was calculated for $48 \mathrm{~h}$ as suggested by Loh and Wang [22]. The reason to calculate the rate by this way, to avoid any errors caused by varied lengths of lag phases, difficulties to find out the required time to achieve complete degradation or if the degradation had stopped. Moreover, many cells did not show any further phenol degradation with increasing time, or it represented the elapsed time for all of the conducted experiments.

\section{Effect of $\mathrm{pH}$ and Temperature on Phenol Degradation}

The ability of $C$. flaccumfaciens to degrade phenol was examined in $700 \mathrm{ppm}$ phenol concentration which, prepared in mineral media C. flaccumfaciens were cultured under different parameters using shaking incubator in the mineral media. Different $\mathrm{pH}(5.5,7$, 8, and 9) was used to assess the effect of $\mathrm{pH}$ on the degradation of phenol by C. flaccumfaciens. Moreover, the effect of different temperatures $(25,28,33$ and $37^{\circ} \mathrm{C}$ ) upon phenol degradation C. flaccumfaciens. was investigated. 


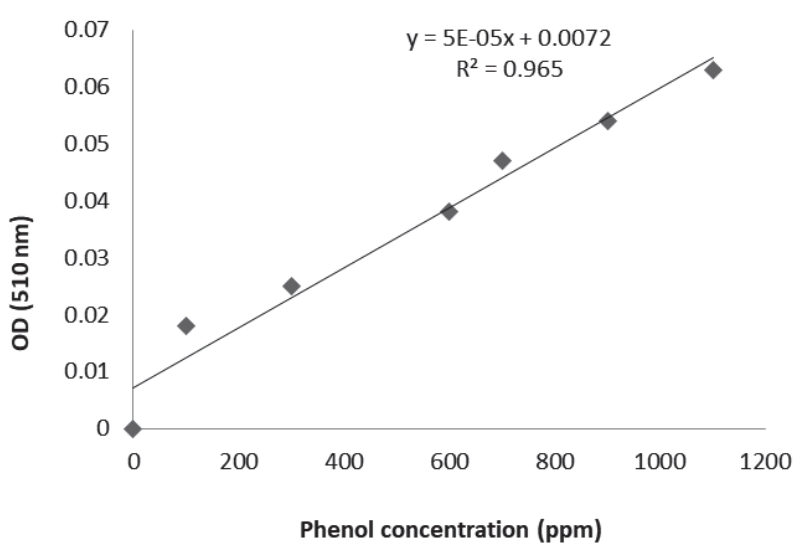

Fig. 1. Standard curve: correlation between different concentration of phenol (0-110 ppm) and absorbance at $510 \mathrm{~nm}$.

\section{Results and Discussion}

\section{Standard Curves}

Initially, in order for us to extract the phenol value, it was necessary to use the standard curve, includes $0,100,300,500,700,900.1100$ and $1200 \mathrm{ppm}$ (Fig. 1). Therefore, the standard curve was considered as a reference to determine the amount of the remaining phenol concentration and calculated it as part per million when samples were taken at different times. Thus in the course of experiments, the following equation $(\mathrm{y}=5 \mathrm{E}-05+0.0072 \mathrm{x}+0.0035)$ was used to predict the concentration of phenol [23].

\section{Substrate Concentration Effect}

The potential of Curtobacterium flaccumfaciens to use diverse aromatic compounds for growth was tried in batch cultures. The bacterium Curtobacterium was confirmed to use the phenol compound as the only sources of carbon and energy, by including it in an minimal phenol medium containing no other organic compounds. To make sure of this, two types were used as a varied negative control to confirm whether or not phenol biodegradation has occurred, and a phenol-free culture containing cells killed by heat. It was noted that there was no activity of biodegradation and thus it was confirmed biological degradation activity of phenol by $C$. flaccumfaciens cells. Therefore, making any cell mass is a function of the using up of these aromatic compounds. Six initial phenol concentrations were used (Figs 2, 3 and 4). To our awareness, this is the initial study linked to biodegradation of the phenol compound by Curtobacterium. In fact, although the biodegradation of phenol compounds by microorganisms is argued exceedingly in the literature $[16,24,25]$, no investigations involving Curtobacterium have been published. C. Alaccumfaciens was capable to biodegrade the phenol effectively at 700-ppm phenol and almost $100 \%$ of the phenol had completely vanished

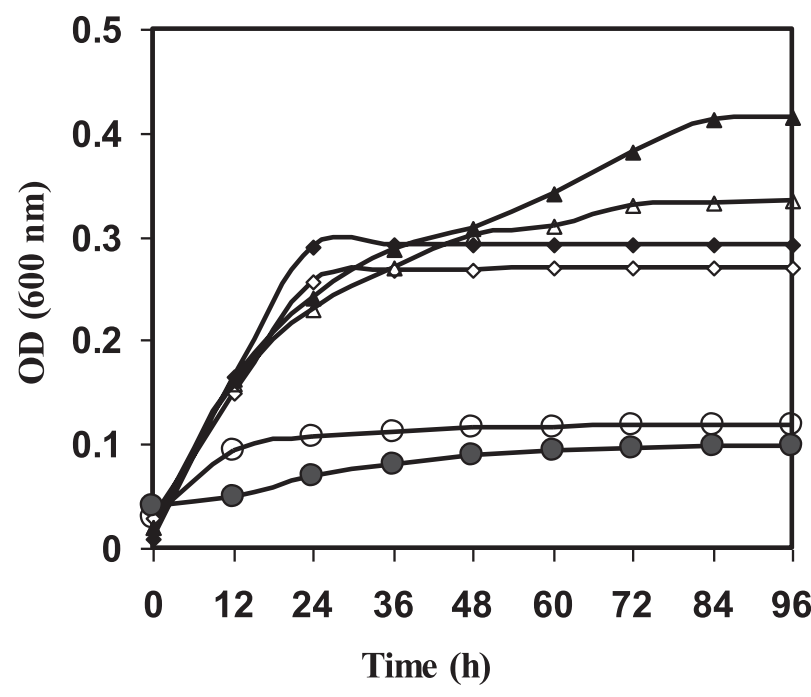

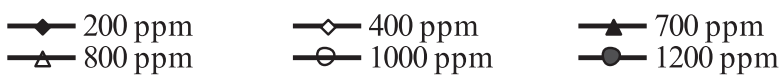

Fig. 2. Effect of phenol concentrations on the growth of Curtobacterium flaccumfaciens.

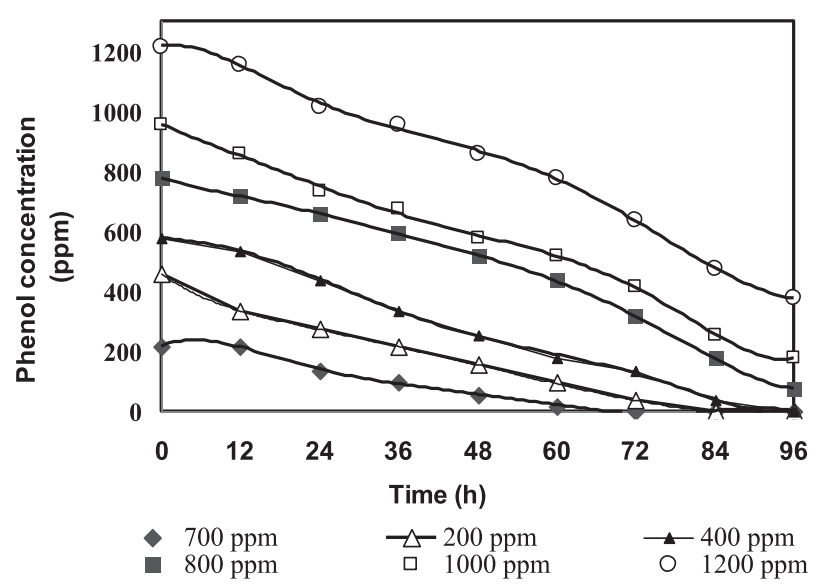

Fig. 3. Effect concentrations on the biodegradation of phenol by Curtobacterium flaccumfaciens.

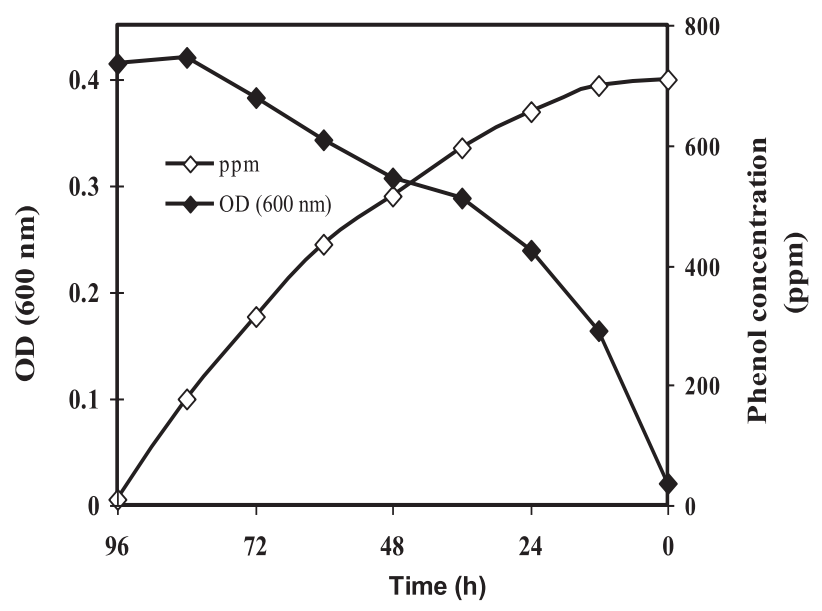

Fig. 4. Biodegradation of phenol versus growth by Curtobacterium flaccumfaciens. 
in a reasonable incubation time (96 h). It has been visible that as the primary concentration of phenol boosts, the degradation rate escalated to a value of $19.4 \mathrm{ppm} / \mathrm{h}$ then began to lower with the additional increasing of the concentration of phenol. This is due to the reality that inhibition of cells were occurred with extra raise in the concentration of phenol. These results were also parallel to the percentage of phenol removal value where $700 \mathrm{ppm}$ resulted in the maximal percentage of removal.

The results of C. Alaccumfaciens were similar to that of Pseudomonas sp. BZD-33 [26], Pseudomonas aeruginosa PDM [27] and Rhodococcus UKMP$5 \mathrm{M}$ [28]. At the same time, it has been observed that many of the oxygenase enzymes and their harboring bacteria that are known to degrade at least one type of aromatic compounds are capable of using diverse types of aromatic compounds as substrate [14, 17, $29,30]$. It must be noted that many previous studies emphasized the necessity of providing an ideal quantity of carbon and nitrogen sources such as yeast extract, which must be adjusted to obtain the optimum rate for biodegradation of phenol or other organic compounds. The reason for the enhanced degradation rate of phenol by $C$. flaccumfaciens cells can be attributed to the fact that phenol is the only carbon source and the amount of phenol-degrading enzymes may be large enough. These bacteria are able to devour this substrate easily and thus are capable to avoid the usual dilution of phenol toxicity. Accordingly, that is why different initial densities of C. flaccumfaciens cells (data not shown) did not affect the time of induction for phenol biodegradation $[2,5$, $19,31,32]$.

\section{The Effect of $\mathrm{pH}$ of Media on the Biodegradation of Phenol}

To ensure a decrease in the final phenol concentration on the culture medium as a result of the biological activities carried out by the C. flaccumfaciens, for each $\mathrm{pH}$, the biological control in the uncultivated culture was used to determine the reason for the decrease in the phenol that occurred as a result of the chemical reaction or otherwise. The tried $\mathrm{pH}$ showed no effect on the amount of phenol that was present in the uncultivated culture. The cells of $C$. Alaccumfaciens showed different rates of phenol degradation due to below the $\mathrm{pH}$ levels. Kinetic parameters during phenol degradation as a function of the varying $\mathrm{pH}$ levels are shown in Table 1 . These parameters were reflected on the variation in the value of phenol dissipation, which appeared as being dependent on the $\mathrm{pH}$ level of the bacterial culture. Thus, it appears from the table that these C. Alaccumfaciens cells ideally sweeten phenol at $\mathrm{pH}$ 7.0. These results showed that $\mathrm{pH} 7.0$ is the best way to obtain the maximum degradation of phenol by bacteria. Enzymes that induce phenol degradation by $C$. Alaccumfaciens cells may have optimum enzymatic activities at $\mathrm{pH}$ 7.0. It has been reported that the optimum $\mathrm{pH}$ of biodegradation of different aromatic compounds was
Table 1. Effect of $\mathrm{pH}$ on the biodegrade rate of phenol by Curtobucterium flaccumfaciens.

\begin{tabular}{|c|c|c|}
\hline Condition & Value & Biodegradation rate $(\mathrm{ppm} / \mathrm{h})$ \\
\hline \multirow{3}{*}{$\mathrm{pH}$} & 5.5 & 8.3 \\
\cline { 2 - 3 } & 7 & 19.4 \\
\cline { 2 - 3 } & 8 & 11.6 \\
\cline { 2 - 3 } & 9 & 11.6 \\
\hline
\end{tabular}

different from one bacterium to another, for example, the optimum $\mathrm{pH}$ of biodegradation of 4-CBA by Arthrobacter is 6.8 [33], and $\mathrm{pH}$ between 8 and 11 were ideal for decomposition. The biosynthesis of phenol and catechol by Halomonas campisalis bacteria for the biological degradation of phenol by Klebsiella oxytoca, was 6.8 [34]. Among these conditions examined, acid and alkaline media (pH 5.5 and more than 7, respectively) favored a lower degradation rate $(8.3$ and $11.6 \mathrm{ppm} / \mathrm{h})$ while neutral culture media $(\mathrm{pH} 7.0)$ exhibited the highest biodegradation rate $(19.4 \mathrm{ppm} / \mathrm{h})$. In $\mathrm{pHs}$ $(5.5,8$ and 9) it could show greater toxicity which in turn lessen the microbial activity including enzymes triggering biodegradation in C. flaccumfaciens [3].

The focus on the microbial degradation of phenols in recent years has resulted in the isolation, culture, adaptation and enrichment of a number of microorganisms that can grow on the compound as a sole carbon and energy source. However, the process might not be fast enough to prevent the ecological hurt [35]. Micro-organisms that degrade phenol were firstly isolated early in 1908 [35]. Recently, several bacterial species utilize phenol and other aromatic compounds as the sole carbon and energy source have been used $[3,36,37]$ in phenol biodegradation studies. Those including Bacillus sp, Pseudomonas sp, Acinetobacter sp, Achromobacter sp. Ewingella Americana, Streptomyces sp, Phanerocheate chrysosporium, Fusarium sp, Corious versicolor, Ralstonia sp. The physiological parameters play a vital role in the growth and biodegradation behavior of any microorganism [38], but maximum growth is achieved only at the optimum conditions of these physiological parameters. Thus different physiological parameters that usually interfere in the biodegradation activity of a microbe are mainly: availability of nutrients, the incubation temperature and $\mathrm{pH}[39]$.

\section{Effect of Incubation Temperature}

The results on the phenol degradation rate when using various incubation temperature (Table 2) displayed that when the variation in rate of phenol degradation between 25 and $37^{\circ} \mathrm{C}$ was considerable, this importance was not observed with the results at 28 and $33^{\circ} \mathrm{C}$. It is obvious that the incubation temperature turns out to be critical beyond $33^{\circ} \mathrm{C}$, thus any extra rise in incubation temperature lead to a sharp reduction 
Table 2. Effect of incubation temperature on the biodegradation rate of phenol by Curtobucterium flaccumfaciens.

\begin{tabular}{|c|c|c|}
\hline Condition & Value & Biodegradation rate $(\mathrm{ppm} / \mathrm{h})$ \\
\hline \multirow{3}{*}{$\begin{array}{c}\text { Incubation } \\
\text { temperature }\left({ }^{\circ} \mathrm{C}\right)\end{array}$} & 25 & 5.2 \\
\cline { 2 - 3 } & 28 & 19 \\
\cline { 2 - 3 } & 33 & 11.6 \\
\cline { 2 - 3 } & 37 & 13.8 \\
\hline
\end{tabular}

in degradation rate of phenol. Therefore, it appears that biodegradation process of phenol could take place at incubation range between $25^{\circ} \mathrm{C}$ and less and $37^{\circ} \mathrm{C}$ or above, with being $28^{\circ} \mathrm{C}$ is the optimal incubation temperature for C. Alaccumfaciens cells. Variation in incubation temperatures obviously had a potent effect on the metabolic fate of the phenol or other organic pollutants, as the mesophilic temperature produced the better situations for their biodegradation, or this could be exclusively as the result of impact of incubation temperature on the activities enzyme(s) involved [40, 41]. It is known that temperature has an important role, sometimes more than the availability of nutrients for the degradation of organic pollutants, including phenol [7]. All biological reactions that participate in the decomposition pathway have an optimum temperature and $\mathrm{pH}$, and therefore will not have the same metabolic rate in different conditions [34]. It is known that each bacterial species has a specific range of optimum growth temperatures, for example it has been reported that Corynebacterum glutamicum decomposes phenol at an appropriate temperature between $30-37^{\circ} \mathrm{C}$ [42]. Likewise, the bacteria Acetobacter sp influenced the effect of phenol at an optimum temperature of $33^{\circ} \mathrm{C}$ [43].

\section{Conclusions}

The data presented here represent the first report about the capability of phenol degradation by $C$. flaccumfaciens isolated from agriculture station soil. This could be an unrivaled organism in the degradation of high concentrations of phenol as compared with that of taking place in other microorganisms. Phenol degradation was most favorably achieved at a $28^{\circ} \mathrm{C}$ incubation temperature and a $\mathrm{pH}$ of 7.0. The next study will involve the characterization of phenol degradation by this bacterium using analysis of GC, HPLC and NMR.

\section{Acknowledgements}

The researchers would like to thank the Deanship of Graduate Studies at the University of Mu'tah for their support for this project.

\section{Conflict of Interest}

The authors declare no conflict of interest.

\section{References}

1. KHLEIFAT K.M., SHAWABKEH R., AL-MAJALI I., TARAWNEH K. Biodegradation kinetics of phenol by Klebsiella oxytoca: effect of carbon and Nitrogen source. Fresenius Environmental Bulletin. 16 (5), 489, 2007.

2. RAI A., GOWRISHETTY K.K., SINGH S., CHAKRABARTY J., BHATTACHARYA P., DUTTA S. Simultaneous Bioremediation of Cyanide, Phenol, and Ammoniacal-N from Synthetic Coke-Oven Wastewater Using Bacillus sp. NITD 19. Journal of Environmental Engineering. 147 (1), 04020143, 2021.

3. KHLEIFAT K.M., ABBOUD M.M., AL-MUSTAFA A.H., AL-SHARAFA K.Y. Effects of carbon source and Vitreoscilla hemoglobin ( $\mathrm{VHb}$ ) on the production of $\beta$-galactosidase in Enterobacter aerogenes. Current microbiology. 53 (4), 277, 2006.

4. ABBOUD M.M., KHLEIFAT K.M., BATARSEH M., TARAWNEH K.A., AL-MUSTAFA A., ALMADADHAH M. Different optimization conditions required for enhancing the biodegradation of linear alkylbenzosulfonate and sodium dodecyl sulfate surfactants by novel consortium of Acinetobacter calcoaceticus and Pantoea agglomerans. Enzyme and Microbial Technology. 41 (4), 432, 2007.

5. WEN Y., LI C., SONG X., YANG Y. Biodegradation of Phenol by Rhodococcus sp. Strain SKC: Characterization and Kinetics Study. Molecules. 25 (16), 3665, 2020.

6. YING W., YE T., BIN H., ZHAO H.-B., BI J.-N.,. CAI B.-L Biodegradation of phenol by free and immobilized Acinetobacter sp. strain PD12. Journal of environmental sciences. 19 (2), 222, 2007.

7. KHLEIFAT K.M., TARAWNEH K.A., WEDYAN M.A., AL-TARAWNEH A.A., AL SHARAFA K. Growth kinetics and toxicity of Enterobacter cloacae grown on linear alkylbenzene sulfonate as sole carbon source. Current microbiology. 57 (4), 364, 2008.

8. LIU Y., ZHANG A., WANG X. Biodegradation of phenol by using free and immobilized cells of Acinetobacter sp. XA05 and Sphingomonas sp. FG03. Biochemical Engineering Journal. 44 (2-3), 187, 2009.

9. EL-NAAS M.H., AL-MUHTASEB S.A., MAKHLOUF S. Biodegradation of phenol by Pseudomonas putida immobilized in polyvinyl alcohol (PVA) gel. Journal of hazardous materials. 164 (2-3), 720, 2009.

10. EL-NAAS M.H., AL-ZUHAIR S., MAKHLOUF S. Batch degradation of phenol in a spouted bed bioreactor system. Journal of Industrial and Engineering Chemistry. 16 (2), 267, 2010

11. ABU RAYYAN W.S., AL-MAJALI I.S., ZAKARIA Z., ABU-ZAITON A.S., ABU DAYYIH W., specific purification of alcohol dehydrogenase from Saccharomyces cerevisiae; qualitative and quantitative characterization. IJBPAS. 8 (12), 2337, 2019.

12. ABBOUD M.M., ALJUNDI I.H., KHLEIFAT K.M., DMOUR S. Biodegradation kinetics and modeling of whey lactose by bacterial hemoglobin VHb-expressing Escherichia coli strain. Biochemical Engineering Journal. 48 (2), 166, 2010. 
13. STOILOVA I., KRASTANOV A., STANCHEV V., DANIEL D., GERGINOVA M., ALEXIEVA Z. Biodegradation of high amounts of phenol, catechol, 2, 4-dichlorophenol and 2, 6-dimethoxyphenol by Aspergillus awamori cells. Enzyme and Microbial Technology. 39 (5), 1036, 2006.

14. KHLEIFAT K.M., AL-LIMOUN M.O., ALSHARAFA K.Y., QARALLEH H., AL TARAWNEH A.A. Tendency of using different aromatic compounds as substrates by 2 , 4-DNT dioxygenase expressed by pJS39 carrying the gene dntA from Burkholderia sp. strain DNT. Bioremediation Journal. 23 (1), 22, 2019.

15. AL-KHALID T., EL-NAAS M.H. Aerobic biodegradation of phenols: a comprehensive review. Critical Reviews in Environmental Science and Technology. 42 (16), 1631, 2012.

16. EREQAT S.I., ABDELKADER A.A., NASEREDDIN A.F., AL-JAWABREH A.O., ZAID T.M., LETNIK I., ABDEEN Z.A. Isolation and characterization of phenol degrading bacterium strain Bacillus thuringiensis J20 from olive waste in Palestine. Journal of Environmental Science and Health, Part A. 53 (1), 39, 2018.

17. ZOU S., ZHANG B., YAN N., ZHANG C., XU H., ZHANG Y., RITTMANN B.E. Competition for molecular oxygen and electron donor between phenol and quinoline during their simultaneous biodegradation. Process biochemistry. 70, 136, 2018.

18. HARVESON R.M., SCHWARTZ H.F., URREA C.A., YONTS C.D. Bacterial wilt of dry-edible beans in the central high plains of the US: past, present, and future. Plant Disease. 99 (12), 1665, 2015.

19. AL-ASOUFI A., KHLAIFAT A., TARAWNEH A.A., ALSHARAFA K., AL-LIMOUN M., KHLEIFAT K. Bacterial Quality of Urinary Tract Infections in Diabetic and Non Diabetics of the Population of Ma'an Province, Jordan. Pakistan journal of biological sciences. 20 (4),179, 2017

20. DER YANG R., HUMPHREY A.E. Dynamic and steady state studies of phenol biodegradation in pure and mixed cultures. Biotechnology and bioengineering. 17 (8), 1211, 1975.

21. BASTOS A., TORNISIELO V., NOZAWA S., TREVORS J., ROSSI A. Phenol metabolism by two microorganisms isolated from Amazonian forest soil samples. Journal of industrial microbiology and biotechnology. 24 (6), 403, 2000.

22. LOH K.-C., WANG S.-J. Enhancement of biodegradation of phenol and a nongrowth substrate 4-chlorophenol by medium augmentation with conventional carbon sources. Biodegradation. 8 (5), 329, 1997.

23. AISAMI A., YASID N.A., ABD SHUKOR M.Y. Optimization of Cultural and Physical Parameters for Phenol Biodegradation by Newly Identified Pseudomonas sp. AQ5-04. Journal of Tropical Life Science. 10 (3), 223, 2020.

24. YOUNIS S.A., EL-GENDY N.S., NASSAR H.N. Biokinetic aspects for biocatalytic remediation of xenobiotics polluted seawater. Journal of Applied Microbiology, 2020.

25. NOGINA T., FOMINA M., DUMANSKAYA T., ZELENA L., KHOMENKO L., MIKHALOVSKY S., PODGORSKYI V., GADD G.M. A new Rhodococcus aetherivorans strain isolated from lubricant-contaminated soil as a prospective phenol-biodegrading agent. Applied Microbiology and Biotechnology, 1, 2020.

26. KE Z., XIANGLING W., JIAN C., JIA C. Biodegradation of diethyl phthalate by Pseudomonas sp. BZD-33 isolated from active sludge. in IOP Conference Series: Earth and Environmental Science. 2019. IOP Publishing.

27. YOUSSEF M., EL-SHATOURY E.H., ALI S.S., ELTAWEEL G.E. Enhancement of phenol degradation by free and immobilized mixed culture of Providencia stuartii PL4 and Pseudomonas aeruginosa PDM isolated from activated sludge. Bioremediation Journal. 23 (2), 53, 2019.

28. SUHAILA Y.N., HASDIANTY A., MAEGALA N., AQLIMA A., HAZWAN A.H., ROSFARIZAN M., ARIFF A. Biotransformation using resting cells of Rhodococcus UKMP-5M for phenol degradation. Biocatalysis and Agricultural Biotechnology. 21, 101309, 2019.

29. MOHITE B.V. Efficient biotransformation of phenol and its derivatives using Streptococcus epidermis by catechol 2, 3-dioxygenase metabolism. Environmental Engineering \& Management Journal (EEMJ). 14 (4), 2015.

30. ARAVIND M.K., KAPPEN J., VARALAKSHMI P., JOHN S.A., ASHOKKUMAR B. Bioengineered Graphene Oxide Microcomposites Containing Metabolically Versatile Paracoccus sp. MKU1 for Enhanced Catechol Degradation. ACS omega. 5 (27), 16752, 2020.

31. SAMADI A., SHARIFI H., NEJAD Z.G., HASANZADEH A., YAGHMAEI S. Biodegradation of 4-Chlorobenzoic Acid by Lysinibacillus macrolides DSM54T and Determination of Optimal Conditions. International Journal of Environmental Research, 1-10, 2020.

32. RUGHÖFT S., VOGEL A.L., JOYE S.B., GUTIERREZ T., KLEINDIENST S. Starvation-dependent inhibition of the hydrocarbon degrader Marinobacter sp. TT1 by a chemical dispersant. Journal of Marine Science and Engineering. 8 (11), 925, 2020.

33. TSOI M.F., GOH N.K., CHIA L.S. Practical Multimedia Courseware Design for Learner's Difficulties in Chemical Education. 1999.

34. SHAWABKEH R., ABU-NAMEH E. Absorption of phenol and methylene blue by activated carbon from pecan shells. Colloid Journal. 69 (3), 355, 2007.

35. EVANS R.J., MCGINNIS J. The influence of autoclaving soybean oil meal on the availability of cystine and methionine for the chick. The Journal of nutrition. 31 (4), 449, 1946.

36. LUCKARIFT H.R., SIZEMORE S.R., FARRINGTON K.E., FULMER P.A., BIFFINGER J.C., NADEAU L.J., JOHNSON G.R. Biodegradation of medium chain hydrocarbons by Acinetobacter venetianus $2 \mathrm{AW}$ immobilized to hair-based adsorbent mats. Biotechnology progress. 27 (6), 1580, 2011.

37. ZHANG Y., LING J., YUAN C., DUBRUILLE R., EMERY P. A role for Drosophila ATX2 in activation of PER translation and circadian behavior. Science. 340 (6134), 879, 2013.

38. TARAWNEH K.A., AL-TAWARAH N.M., ABDELGHANI A.H., AL-MAJALI A.M., KHLEIFAT K.M. Characterization of verotoxigenic Escherichia coli (VTEC) isolates from faeces of small ruminants and environmental samples in Southern Jordan. Journal of basic microbiology. 49 (3), 310, 2009.

39. ALTHUNIBAT O.Y., QARALLEH H., AL-DALIN S.Y., ABBOUD M., KHLEIFAT K., MAJALI I.S., ALDAL'IN H.K., RAYYAN W.A., JAAFRAA A. Effect of thymol and carvacrol, the major components of Thymus capitatus on the growth of Pseudomonas aeruginosa. J Pure Appl Microbiol. 10 (1), 367, 2016.

40. BESHAY U., ABD-EL-HALEEM D., MOAWAD H., ZAKI S. Phenol biodegradation by free and immobilized 
Acinetobacter. Biotechnology letters. 24 (15), 1295, 2002.

41. LEVEN L., SCHNÜRER A. Effects of temperature on biological degradation of phenols, benzoates and phthalates under methanogenic conditions. International Biodeterioration \& Biodegradation. 55 (2), 153, 2005.

42. BHARGAVI B.J., RAFI M.M., RAO D.M. Effect of physicochemical conditions on phenol degradation by
Corynebacterium glutamicum: A focus on phenol catabolic enzymes. 2016.

43. ZENG H.-Y., CAO X.-L., XIONG L.-B., CAI X.-L., HUANG L.-Q., ZHANG C.-Y., LI Y.-Q. Microbiological degradation of phenol using two co-aggregating bacterial strains. Environmental earth sciences. 71 (3), 1339, 2014. 